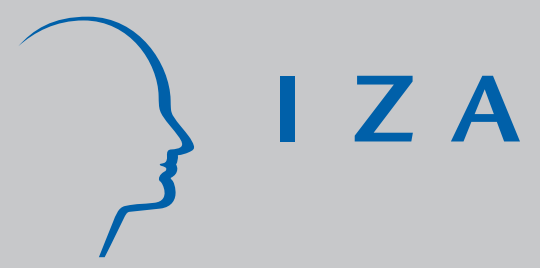

IZA DP No. 1090

Temporary Employment Agencies: A Route for Immigrants to Enter the Labour Market?

PernillaAndersson

Eskil Wadensjö

March 2004 


\title{
Temporary Employment Agencies: A Route for Immigrants to Enter the Labour Market?
}

\author{
Pernilla Andersson \\ Swedish Institute for Social Research, \\ Stockholm University \\ Eskil Wadensjö \\ Swedish Institute for Social Research, \\ Stockholm University and IZA Bonn
}

\section{Discussion Paper No. 1090 \\ March 2004}

\author{
IZA \\ P.O. Box 7240 \\ 53072 Bonn \\ Germany \\ Phone: +49-228-3894-0 \\ Fax: +49-228-3894-180 \\ Email: iza@iza.org
}

\begin{abstract}
Any opinions expressed here are those of the author(s) and not those of the institute. Research disseminated by IZA may include views on policy, but the institute itself takes no institutional policy positions.
\end{abstract}

The Institute for the Study of Labor (IZA) in Bonn is a local and virtual international research center and a place of communication between science, politics and business. IZA is an independent nonprofit company supported by Deutsche Post World Net. The center is associated with the University of Bonn and offers a stimulating research environment through its research networks, research support, and visitors and doctoral programs. IZA engages in (i) original and internationally competitive research in all fields of labor economics, (ii) development of policy concepts, and (iii) dissemination of research results and concepts to the interested public.

IZA Discussion Papers often represent preliminary work and are circulated to encourage discussion. Citation of such a paper should account for its provisional character. A revised version may be available on the IZA website (www.iza.org) or directly from the author. 


\section{ABSTRACT \\ Temporary Employment Agencies: A Route for Immigrants to Enter the Labour Market?*}

We study immigrants in temporary employment agencies in Sweden using a unique data set that covers all aged 16-64 who were employed by temporary employment agencies (TEAs) in Sweden in November 1999, with information on their employment status in 1998 and 2000. We find that young people, women, people living in big cities, and immigrants are overrepresented in the TEAs. Grouping immigrants after origin shows that immigrants from Africa, Asia and South America are greatly overrepresented in the sector. Immigrants are on average slightly older than the natives who work in TEAs, they are more often married, and women are less overrepresented among those born outside of Sweden. The immigrants are overrepresented among those with the lowest education and those with higher education. The mobility between employment status (employed in a TEA, other type of employment, unemployed, studying) differs between immigrants and natives in several respects. One result is that immigrants more often leave a TEA for another type of employment, which could be interpreted as employment in a TEA being used as a stepping stone to the labour market.

JEL Classification: J15, J40, J61

Keywords: immigrant workers, temporary agency work, contingent labour, temporary work

Corresponding author:

Eskil Wadensjö

Swedish Institute for Social Research

Stockholm University

10691 Stockholm

Sweden

Email: Eskil.Wadensjo@sofi.su.se

\footnotetext{
${ }^{*}$ We would like to thank seminar participants at the ESPE conference in New York in June 2003; IFAU in Uppsala, Department of Economics at Växjö University; CELMS, Department of Economics, Gothenburg University; Statistics Sweden, Örebro; and the Swedish Institute for Social Research, Stockholm University for helpful comments. Financial support from IFAU is gratefully acknowledged.
} 
1. Introduction - temporary employment agencies - a dead-end street or a route to the labour market for immigrants?

Immigrants, especially those from non-European countries, are generally in a precarious situation in the Swedish labour market. Their labour force participation is lower and unemployment higher than for the non-immigrant population. The immigrants who have jobs less often have permanent jobs in the primary labour market. Immigrants are overrepresented among the self-employed and among those who have less stable employment. One form of contingent employment is to take work in temporary employment agencies.

This paper studies immigrants in temporary employment agencies in Sweden. We use a unique data set that covers all aged 16-64 who were employed by temporary employment agencies (TEA) in Sweden in November 1999, with information on their employment status in 1998 and 2000. We have information on their age, gender, marital status, immigrant status, education, region, income etc. The data set also covers information relating to all people aged 16-64 in 1999 irrespective of if they are employed by a temporary employment agency or not with the same type of information. We also have information on all who were employed in 2000 by a TEA which was in business in 1999 .

The second section of the paper surveys research on temporary employment agencies. The research is scarce mainly due to lack of databases that cover people employed by employment agencies. In the third section of the paper we present the database that is used for the present study in more detail.

In section 4 we study the factors that influence employment by temporary employment agencies. We find that young people, women, people living in big cities, and immigrants (first generation but also second-generation immigrants) are overrepresented. Grouping immigrants after origin shows that immigrants from Africa, Asia and South America are greatly overrepresented in the sector. However, immigrants from countries that are geographically close to Sweden are not overrepresented in temporary employment agencies compared to people who were born in Sweden.

In section 5 the characteristics of immigrants employed by temporary employment agencies are compared with natives employed in the same sector. Immigrants are on 
average slightly older than the natives who work in TEAs, they are more often married, and women are less overrepresented among those born outside of Sweden. The immigrants are overrepresented among those with the lowest education and those with higher education. The immigrants in TEAs more often live in big cities than natives in TEAs. To a large extent the same type of differences are also found when comparing all employed immigrants and natives. A comparison between immigrants who come from different areas shows large differences in characteristics.

In section 6, sector mobility is studied. The mobility between employment status (employed in a TEA, other type of employment, unemployed, studying) in year 1998 and in year 2000 is examined. The pattern differs between immigrants and natives in several respects. With multinomial logit analysis the factors that influence the probability of going from a job in a temporary employment agency (in 1999) to another type of employment (in 2000) are studied. One result is that immigrants more often leave for another type of employment. Other factors such as age, gender, education, and if the person lives in a big city are also of importance.

In section 7 groups with different mobility patterns are compared. One group consists of those employed in a TEA all three years, another of those unemployed in 1998, employed in a TEA in 1999, and with another type of employment in 2000. Immigrants are overrepresented in the second group, which could be characterized as TEA being a stepping stone to the labour market. We also present information on the income development for those with different employment status careers.

In section 8 the main results are summarized and some conclusions are drawn.

\section{Research on temporary employment agencies}

Temporary employment agencies have a long history. However, up to the 1990s few researchers showed interest in the sector. In Sweden and some other European countries this may be due to that their activities first became legal in that decade. Another factor may be a lack of good statistical information, a problem which still exists. In the last few years the interest in the sector has grown and a number of studies have been published, especially in the United States. Below, a short survey is given of one of the questions dealt with: Why 
does a market for temporary employment agencies exist? The answer to this question may contribute to the knowledge of why some groups are overrepresented in the industry.

Why are some people hired from temporary employment agencies instead of being employed directly on a regular basis? The answer to this question has to be found on the demand side, the supply side or a combination of the two sides of the labour market. There are some different answers to this question put forward in the literature in the field. ${ }^{1}$

The first explanation for the phenomenon is that the temporary employment agencies combine many part-time and part-year jobs to full-time and full-year jobs. Employers in many cases only have a demand for people to work with certain tasks for a few hours a day, or full-time for only a few days or weeks. Most people want to work more than that. In principle a person could himself combine a number of part-time or part-year jobs to full-time employment, but it takes time and it could lead to a disadvantage regarding different forms of fringe benefits such as for example insurances which are dependent on a minimum working time with one employer. The temporary employment agency combines several part-time or part-year jobs to full-time jobs (or longer part-time jobs).

A second explanation is based on that it is costly to recruit people. There are costs for advertisements, interviews, training etc. These costs may be of minor importance when the employment is expected to last for a long period, but they could be prohibitive if the expected period is short. And there is a demand for short employment spells, for example to match short-run variations in product demand, at seasonal variations, when regular employees are on sick leave, and for the time when recruitment for a permanent position is carried out. When an employer uses a temporary employment agency that agency covers most of the recruitment costs but the agency can distribute these costs over many hiring companies. Another related advantage for the company hiring workers is that the recruitment often is faster if a temporary employment agency is used instead of alternative methods.

A third explanation is that the temporary employment agencies are better at finding people with the required competence, maybe especially in comparison to small firms. In such cases a job in a temporary employment agency may also serve as a trial employment.

\footnotetext{
${ }^{1}$ For an analysis see Houseman (1997).
} 
The second and third explanations build on two types of uncertainty. The second explanation relates to uncertainty regarding the extent and duration of the demand for labour, and the third on uncertainty regarding the quality of the supply of labour. ${ }^{2}$

The fourth explanation builds on that laws and collective agreements make it costly for employers to reduce the workforce or change its composition. It is much easier to change the volume or composition of the personnel hired from a temporary employment agency. If a firm does not want to hire a worker any longer the temporary employment agency may find another firm willing to hire the same worker. Increased employment security according to law or agreement may lead to an increased demand for the services of temporary employment agencies. ${ }^{3}$

In the United States a fifth explanation has also been an important part of the debate and the research on the temporary employment agencies. That is that by hiring a temp instead of employing the worker himself an employer is able to reduce the wage costs due to that the wages and especially the insurance costs (e.g. for health insurance) are lower for those hired from a temporary employment agency than for those hired directly by the employer. ${ }^{4}$ Sweden has a different industrial relation system with collective agreements covering most of the labour market including those working in temporary employment agencies. This means that the lower wage cost explanation is probably of less relevance regarding the Swedish labour market.

There is a discussion on how the different explanatory factors could be used to explain the expansion in the temporary employment industry. This is especially so for the legal framework. In the United States, employment protection has gradually been enhanced mainly by decisions taken in the courts on the state level. These changes have taken place at different times in different states which facilitate studies of the effects of the changes. The studies show that the changes have the expected effects - an increase in the demand for the services of the temporary employment agencies. Another result is that a high union density means a higher market share for the temporary employment agencies. This fact,

\footnotetext{
${ }^{2}$ See Milner and Pinker (2000) for a theoretical analysis of the two models of explanation.

${ }^{3}$ See Autor (2000) and Miles (2000) for studies of the importance of the stricter rules for employment protection on the development of temporary employment agencies in the United States.

${ }^{4}$ See Golden (1996) for a study which gives some support to this hypothesis.
} 
however, cannot contribute to explain the development over time since union density has declined during the last decades in the United States.

The first of the five explanations presented above is that the matching in the labour market is facilitated by the temporary employment agencies (a combined demand and supply side explanation). The other four explanations are different forms of demand side explanations - the employers get lower costs by utilizing temporary employment agencies. There may also be supply side factors. Some people may prefer a job in a temporary employment agency compared to an ordinary job due to that it is more flexible as regards the number of working hours and also due to that it makes it easier to switch between different places of work. For other individuals an employment in a TEA can be a way of finding a regular employment. Those who are hired out to firms have a possibility to show their skills and ability. This should be compared to a situation where unemployed are looking for regular jobs by sending applications and going to interviews. In this situation they have to make an impression on the employer during a short period of time and for some groups on the labour market such as young people and immigrants, in general those without experience on this particular labour market, it can be difficult to convince the employer to hire him or her. For these groups, a period of employment in a TEA can be a way of getting to know the labour market and make contacts with different firms and employers. To look for a job in this way can in some cases be more efficient than to search for a job in a more traditional way.

As was mentioned in the introduction, the purpose of this study is to describe the groups who work in this particular industry. We also analyse the flows to and from the TEI. The focus of this paper is on differences between natives and immigrants concerning their relative representation in the industry and concerning their respective flow patterns. Our main hypotheses are that immigrants are overrepresented in the TEI and if they do work in this industry, they are more likely to enter it from unemployment and leave the industry for an employment in another industry. It is our belief that in particular immigrants are those who use an employment in a TEA as a way of finding a regular employment.

\section{Data}


The purpose of this study is, by using a unique dataset, to study the people employed in the Temporary Employment Industry (TEI) and the flows to and from that industry. By doing so we are able to describe differences and similarities between natives and immigrants and between different groups of immigrants. By combining the employment status in 1998 and 2000 we can distinguish between different patterns.

Our main population consists of all individuals between 16 and 64 years of age who lived in Sweden in November 1999. Information on these individuals is gathered from Statistics Sweden's register based labour market statistics (RAMS). Using this data we have information an age, gender, marital status, place of birth, parents' birth country, education, place of residence, employment status and annual income for about 5 million individuals. In the main population we identify, by using the same definitions as Statistics Sweden, the groups who were employed and unemployed in November 1999.

To identify the population we are primarily concerned with, all who in November 1999 were employed were matched with firms classified as TEAs $^{5}$ to find all individuals employed in a TEA in November 1999. This population consists of 18296 individuals. Of these, 15847 individuals were born in Sweden and 2449 individuals were born in another country. To be able to study the flows to and from the TEI, we use also information for 1998 and 2000.

As earlier mentioned, we are also interested in looking at the flows from unemployment to the TEI. To be able to do this, we have studied the individuals who were unemployed in 1999 and those who were employed in a TEA in 2000. Figure 1 shows our populations and the flows we are interested in.

\footnotetext{
5 The classification of firms as TEA started with a register from Statistics Sweden with names and addresses to firms in an industry where one typically can find these kinds of firms. Additional TEAs were found on the Internet, on the Yellow Pages and in a register over firms who are members of SPUR (the employer organization in the TEI). During the spring 2000 the firms were contacted to judge which of them that were running its business in 1999.
} 


\section{Figure 1}

All individuals between 16 and 64 years of age living in Sweden December, 311999

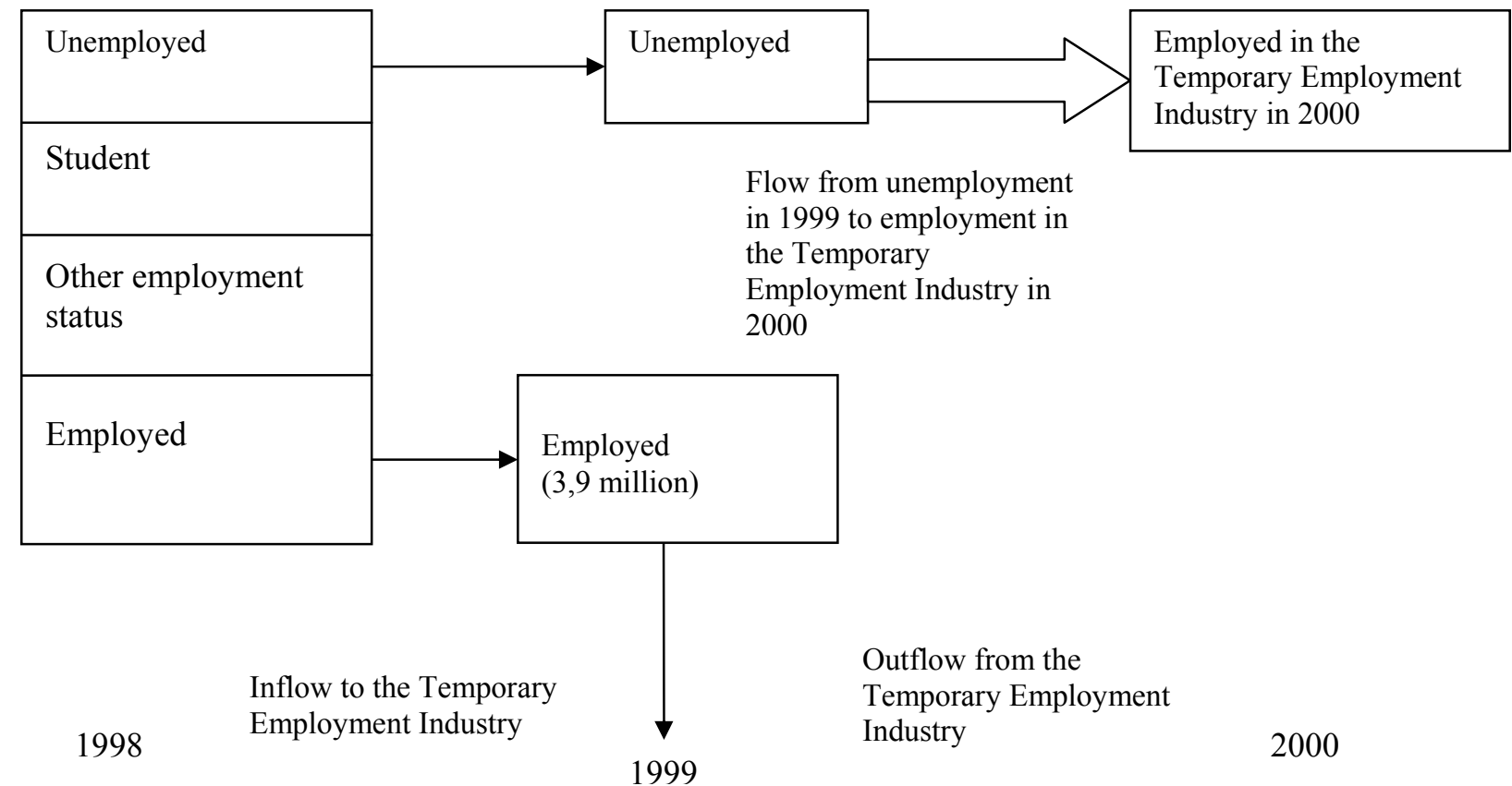

\begin{tabular}{|c|c|c|}
\hline $\begin{array}{l}\text { Employed in the } \\
\text { Temporary } \\
\text { Employment } \\
\text { Industry }\end{array}$ & \multirow{5}{*}{$\begin{array}{l}\text { Employed in the } \\
\text { Temporary } \\
\text { Employment Industry }\end{array}$} & $\begin{array}{l}\text { Employed in the } \\
\text { Temporary } \\
\text { Employment } \\
\text { Industry }\end{array}$ \\
\hline $\begin{array}{l}\text { Employed in } \\
\text { another industry }\end{array}$ & & $\begin{array}{l}\text { Employed in } \\
\text { another industry }\end{array}$ \\
\hline Student & & Student \\
\hline Unemployed & & Unemployed \\
\hline Other status & & Other status \\
\hline
\end{tabular}

(18 296)

(18 296)

(18 296) 
In the data we cannot distinguish between people with different work tasks within the TEI. This means that we cannot determine who are employed to be hired out to other employers and who have administrative work tasks in a TEA. However, the second category of employees is only a minor part of all employed in the TEI.

As was mentioned earlier we use annual data from administrative registers. An advantage is that we have reliable information for each individual, but there is a problem associated with using annual data when defining employment status. We only have information on whether an individual has been employed or not, and in which industry he or she was employed in for one month during the year (November). We also know if an individual has been registered as a student during the fall semester for each year and if he/she has received unemployment insurance benefits during the year. The problem is that an individual can have done several things during one year; for example both been a student and been unemployed. To deal with this problem we have used the available information to construct groups that are mutually exclusive. A detailed description is given in the Appendix to this paper.

The block arrows in figure 1 indicate which flows we are interested in and have estimated regressions for the probability to follow. By using the panel we look at the probability of having a certain employment status in 1998 and in 2000 given that the individual was employed in a TEA in 1999. We have defined five different employment statuses for each year and estimate the probabilities by using multinomial logit regressions. This method makes it possible to compare the probability of having been unemployed in 1998 with for example the probability of having been employed in another industry than the TEI. With the same estimation method we have looked at the probability of having a certain mobility pattern compared to other patterns. Two patterns are of special interest. The first consists of being unemployed in 1998 and employed in another industry in 2000. In this group the probably find those who use employment in a TEA as a way to enter the regular labour market. The second pattern of interest is to have been employed in the TEI in all three years. In this group we probably find those who have chosen this employment form as a long term alternative to regular employment, but also those that are "stuck" in this industry and cannot find any better alternative. We assume that it is positive to follow the path from unemployment in 1998 to employment in another industry in 2000, but to investigate this 
further we look at the income development over the three years included in the study. This is done both for annual labour income and for annual income including employment-related transfer payments. A problem is that the annual income for an individual employed in a TEA in November may partly come from other industries than the TEI. If he/she were employed in another industry at the beginning of the year, for example, the income from that employment is also included in the annual income. ${ }^{6}$

${ }^{6}$ The transfers added to the annual income to get annual gross income are unemployment insurance benefits and social security transfers as sickness benefits and parental leave benefits. 
4. Immigrant representation among those employed in the temporary employment agencies In this section we study the factors that influence that an individual is employed by a temporary employment agency. We will do so firstly by descriptive statistics comparing those employed in the TEI with all employed. See Table 1.

From the table we find that some groups are overrepresented. Women are overrepresented in the TEI, and those employed in that industry are on average younger than all the employed. The average age is 34.8 years compared to 41.1 years. Those working in the TEI are also more often unmarried than all employed, which is probably mainly related to the difference in age. The industry is also strongly overrepresented in the big cities, especially Stockholm. And, which is of special interest for this study, immigrants are overrepresented in the TEI. Among those employed in the TEI 13.4 per cent were born outside of Sweden compared to 9.7 per cent among all employed. Even those who were born in Sweden but whose parents are immigrants are overrepresented. Grouping immigrants after origin shows that immigrants who come from countries that are geographically close to Sweden are not overrepresented in temporary employment agencies in comparison to people who were born in Sweden. Immigrants from Africa, South America and Asia are overrepresented while immigrants from the Nordic countries are underrepresented.

As immigrants are overrepresented in big cities and younger than natives on average, the overrepresentation of immigrants could possibly be explained by these differences. We will therefore use probit analysis in the next step. See Table 2 which shows estimations of three different models. To deal with the heterogeneity within the group of immigrants, variables representing different groups of immigrants are introduced in Model 2 and Model 3.

Model 1 shows that immigrants are overrepresented in the TEI. This is case for both first and second generation immigrants. The effect is larger for the first generation immigrants. The results for the other variables that are included - age, gender, education, region, marital status - go in the same direction as in the descriptive statistics shown in Table 1. 
In Model 2 separate variables are introduced that represent various regions of origin. It shows that those who come from the Nordic countries, other EU countries and Oceania are not overrepresented in the TEI compared to those who were born in Sweden. Those who come from Africa, North and South America and especially those from Asia are however overrepresented. In Model 3 separate variables are introduced that represent immigrants who arrived in different periods. Immigrants who arrived to Sweden in 1966 or later are overrepresented. The overrepresentation is largest for those who arrived in the period from 1986 to 1993.

So far we could only conclude that among all employed in 1999 an immigrant is more likely to be employed in the business in focus than natives. The first part of the hypothesis is then supported.

\section{What characterizes immigrants employed by the temporary employment agencies?}

In the preceding section we found that immigrants were overrepresented in the TEI. In this section we will study the characteristics of immigrants who are employed by temporary employment agencies. As a start we will compare this group with natives employed in the same sector. See Table 3. We will also compare immigrants in the TEI with all employed immigrants. See Table 4. We will also compare different immigrant groups. We divide immigrants into four different groups. The first consists of individuals who were born in one of the Nordic countries, the second are individuals who were born within the European Union, North America and Oceania, and the third are individuals who were born in a European country which is not a member of the European Union and Soviet Union. The last group consists of those who were born in Africa, Asia or South America. We call them "North", "West", “East” and "South”. See Table 5.

The share of women employed in the TEI is larger among natives (61.1 per cent) than among immigrants (53.5), but women are in the majority in the TEI even among immigrants. Women are overrepresented in the TEI also in comparison with all employed immigrants. Of all immigrants employed in November 1999, 48.6 per cent were women. The female share differs considerably between immigrants from different regions. Among 
those born in the Nordic countries almost 73 per cent are women compared to only 42 per cent of those born in Africa, Asia or South America.

Immigrants in the TEI are slightly older on average than natives in the same industry. There are fewer immigrants in the two youngest cohorts. Immigrants in the TEI are younger, however, than all employed immigrants, but the difference is smaller than the corresponding difference for the total population. The immigrants from the North are the oldest (42.8 years) and immigrants from the South the youngest (32.8 years) on average. The differences in marital status are quite noticeable. In general, immigrants in the TEI are less often unmarried than natives in the same industry. Only a part of this may be explained by that the immigrants are slightly older, but the differences are large between the immigrant groups and not related to the average age of the group.

There are no major differences in education level between natives and immigrants in the TEI. The immigrants are slightly overrepresented among those with the shortest education. A comparison of the different immigrant groups shows that this overrepresentation is mainly to be found among those from the North and the South.

The immigrants in the TEI are overrepresented in the three big cities (Stockholm, Gothenburg and Malmoe) both compared to natives in the TEI, and compared to all employed immigrants.

Individuals born in Asia are the largest group of immigrants in the TEI. Almost one third of the immigrants belong to this group. They are also overrepresented compared to their share of all employed immigrants. Those who were born in the Nordic countries on the other hand are underrepresented in the TEI compared to their share of all employed immigrants.

\section{Labour market mobility for those employed by the temporary employment agencies}

One issue in the debate regarding the temporary employment agencies is whether they function as a route to the ordinary labour market. Relating this issue to differences between immigrants and natives, as is the purpose of the study, the question is; why expect that immigrants are more likely to use an employment in a TEA as a route to the ordinary labour market? Certain groups of immigrants are more likely to have experienced discrimination 
of some form than natives are. The employers may when hiring have larger difficulties to evaluate the capacity of immigrant workers than native workers, which may lead to statistical discrimination. If on the other hand the worker is hired through a temporary employment agency that company makes the evaluation and takes the risk. And temporary employment agencies may have a comparative advantage in the evaluation of workers. The immigrant worker may in this way be able to show his capacity and in some cases get an ordinary job in the company which have hired him. Assuming immigrants from these groups are aware of this, it is reasonable for them to view an employment in a TEA as a route to regular employment.

In this section we first present flow matrices between 1998 and 2000 to illustrate how different groups move between employment statuses. The second step is to estimate a probit regression to study the factors that influence the propensity to leave unemployment in 1999 to work in a TEA in 2000. We then continue with multinomial logit regressions where probabilities for having different statuses are estimated. This is done both for 1998 and 2000. We especially focus on country of origin while controlling for age, gender, marital status, education and region.

To start with, we look at the flows to and from the TEI for the whole group of immigrants compared to natives. See Table 6 . The patterns for the two groups are similar, while the levels differ. As was mentioned before, the transition paths we are most interested in are for those who were employed in a TEA in 1998 and 2000, and those who were unemployed in 1998 and employed in another industry in 2000. For natives, these groups consist of 22.3 per cent and 2.8 per cent. For immigrants, the percentage shares are 18.5 and 4.8 respectively. It is more common for immigrants to follow the path from unemployment to employment in another industry.

We will now compare the four groups of immigrants (see Table 7). In some cases there are larger differences between different groups of immigrants than between natives and immigrants. Immigrants from the "East" and the "South" show the same kind of pattern, while immigrants from the "North" and the "West" have a pattern similar to that of the natives. As we have shown earlier, immigrants from the first two groups are overrepresented in the TEI, compared to the entire group of employed people. The share 
employed in a TEA in 1998 is lower for those who come from the "East" and the "South" than for those who come from the "North" and the "West". This is also the case in year 2000. It is much more common that immigrants from the "East" and the "South" enter the TEI as students. In 1998 we also have a large group of immigrants from the "South" that had another occupational status in 1998, i.e. it is more common that they were out of the labour force. These differences are not surprising. Immigrants from the "South" and the "East" are more likely to be refugees who have not been in Sweden for very long.

Unemployed people who enter the TEA are a group of particular interest. The idea is that immigrants who are unemployed are more likely to take an employment in a TEA than unemployed natives. However, the results presented in table 8 are not consistent with this idea. To further investigate this matter we use the population of all individuals who were unemployed in 1999 and estimate the probabilities for those individuals to work in a TEA in 2000. We find that unemployed immigrants are not significantly more often than natives going to a TEA, taken into account differences in age, gender, etc.

A bit surprising is the result that unemployed second generation immigrants significantly more often than natives become employed by a TEA. Another result is that unemployed women less often than unemployed men get employment in a TEA. Younger unemployed people are more often employed by TEAs than older unemployed people, and unemployed people living in Stockholm and Gothenburg are more often becoming employed by a TEA. As a third step we estimate a multinomial logit for the probability of having different employment statuses in 1998. See Table 9. As a comparison group in the multinomial logit regression, we use employment in a TEA. The results are consistent with our earlier discussion. Immigrants from the "South" and the "East" employed in the TEI significantly more often have been students, unemployed or of having another occupational status than natives. Generally, individuals having these statuses are those who may be entering the Swedish labour market for the first time, or re-entering if they have been unemployed. We find almost the same result concerning the youngest cohorts. One conclusion is that it seems to be quite a few immigrants who use employment in a TEA as a way into the labour market. We do not at all find this pattern for natives, which would suggest that there could 
be a difference between immigrants and natives concerning the reasons for why they choose to enter the TEI.

This result together with the results presented in table 8 give us an important insight. Given that an individual was unemployed in 1999 , there is no difference in the probability of entering the TEI in 2000. Given that an individual did enter the TEI in 1999 immigrants are more likely to have been unemployed in 1998 compared to natives.

Studying the outflow from the TEI in 2000 we use employment in another sector as the comparison group as this is the largest group (see Table 10). The result of this regression is not as striking as for the occupational status in 1998. One result is that immigrants from the "East" and the "South" are less likely to be employed in a TEA in 2000, compared to natives, than to be employed in another industry. In other words, they are more likely to leave the TEI. This gives some support to the hypothesis that immigrants, at least from some areas, use employment in a TEA as a way into regular employment. However, we also find that immigrants from the "South" are more likely, compared to natives, to be unemployed in year 2000 than of working in a TEA.

\section{Differences between groups with different mobility patterns.}

In this section we explicitly look at the characteristics of individuals who work in the TEI in all three years and of individuals who were unemployed in 1998 and employed in another industry in 2000 . We also estimate the probabilities of belonging to a group that follows one of these paths. Finally, we study the income development for the different groups.

The paths we analyse in this paper are chosen so as to represent different reasons why one decides to work in a TEA (see Table 11). The group of individuals who are employed in a TEA during all three years can be seen as representing those who have a job in a TEA on a more permanent basis. This could be due to that they prefer this type of employment but also be a result of lack of alternative opportunities. The other group consisting of individuals who were unemployed in 1998 and employed in another industry in 2000, represents a group of individuals that can be assumed to use employment in the TEI as a route to the regular labour market (see Table 12). 
When comparing natives and immigrants who worked in a TEA during all three years, the most visible result is that there are no great differences. On average, they are about the same age, the share of women is almost the same and the educational level appears to be the same. However, it is important to note that almost 40 per cent of the immigrants were born in the Nordic countries and we know that this group is quite similar to natives in the labour market. Most immigrants from the Nordic countries came to Sweden between 1973 and 1985, and only 4.6 per cent during the second half of the 1990s.

Among those who were unemployed in 1998 and employed in another industry in 2000, the share of women is 50 percent among natives and only 38 per cent among immigrants (see Table 12). The natives are slightly younger than the immigrants on average. The share of individuals over 45 years is greater among immigrants than among natives. More than half of the immigrants having this mobility pattern were born in countries belonging to the group "South". 65.3 per cent of the immigrants in this group came to Sweden after 1986, compared to 34.3 percent in the stable group.

A conclusion from this analysis is that immigrants from the "South" more often belong to the volatile group than the stable group. This implies that they use this employment form to a larger extent as a way out of unemployment to employment in another industry. Immigrants from the "South" are also overrepresented in the TEI compared to all employed.

The probabilities of following the two paths of interest are compared to all the other paths with multinomial regression (see Table 13). The result is consistent with our earlier conclusions. Immigrants born in the "South" (Africa, Asia, and South America) are more likely than natives to follow the path from unemployment to employment in another industry, compared to all other possible paths. On the other hand they are underrepresented among the stable group. We also find that immigrants who were born in the "West" (EU 12, North America, and Oceania) are more likely to follow this path.

We see from the regressions that women have a significantly lower probability of taking the path from unemployment to employment in another industry than men do. However, they do not have a higher probability than men of belonging to the stable group either, which is kind of remarkable. Women are more likely than men to belong to one of the other 
14 paths. Immigrants belonging to the overrepresented groups have a higher probability of belonging to the volatile group compared to natives.

We have implicitly assumed that going from unemployment to employment in another industry via a TEA is a good thing. To study if this is the case we have studied the income development over the three years. See Table 14 and 15. Earnings increase from 1998 to 2000. The increase from 1999 to 2000 is larger for the group of individuals that went from employment in a TEA to employment in another industry than for those who stayed in the TEI. This is the case for both natives and immigrants. Immigrants who follow the path from unemployment in 1998 to employment in 2000 have a higher increase in annual earnings between 1999 and 2000 than natives who follow the same path. Immigrants in this group have higher earnings in 1999 and 2000 than natives. The same pattern is found if the gross labour incomes are studied. Concerning the stable group (TEA in all three years) the increase between 1999 and 2000 is about the same for the two groups, but in this case natives have higher incomes.

\section{Conclusions/Discussion}

Those who are new on the Swedish labour market are more likely to work in the TEI In the first place and they are more likely to use this kind of employment as passage from different occupational statuses in general, and as a way from unemployment to employment in another industry, in particular. Individuals can be considered both as new in terms of age and in terms of the number of years that they have lived in Sweden. By this reasoning we can explain both why immigrants from the southern countries are more likely to work in the TEI, and the large share of young people. These groups are also the ones who are most likely to leave this industry for employment in another industry. An answer to the question about whether this form of occupation can work as a route to regular employment for groups that are generally in a precarious situation in the Swedish labour market is both yes and no. If unemployed immigrants enter the TEI, they seem to have a good chance of leaving it for employment in another industry. Unemployed immigrants, however, do not enter the TEI to a higher extent than what unemployed natives do. 
In section two we presented some explanations for why some people are overrepresented in the TEI. The explanations are both based on that some groups prefer a job in the TEI and that some groups have few alternatives and that they select a job in TEA lacking better alternatives. This study gives mainly support to the second story. The groups overrepresented in the TEI are mainly those who do not have a very strong position in the labour market.

References

Affärsvärlden (2001), Konsultguiden, "Hyrvärk".

Andersson, Pernilla and Wadensjö, Eskil (2002), "Vem arbetar i bemanningsbranschen?", Arbetsmarknad \& Arbetsliv, Vol. 8, pp. 257-71.

Autor, David H. (2000), "Outsourcing at Will: Unjust Dismissal Doctrine and the Growth of Temporary Help Employment”, MIT and NBER, working paper, February.

Friberg, Kent, Olli, Åsa and Wadensjö, Eskil (1999), Privat förmedling av arbete i Sverige, Institutet för social forskning, Stockholms universitet, Stockholm.

Fridén, Lennart, Hedén, Ylva and Wadensjö, Eskil (2000), "Personaluthyrningsföretag en bro till arbetsmarknaden?” Bilaga 2 till Mångfaldsprojektet.

Golden, Lonnie (1996), "The Expansion of Temporary Help Employment in the U.S., 1982-1992: A Test of Alternative Explanations", Applied Economics, Vol. 28, pp. $1127-41$.

Houseman, Susan N. (1997), "Temporary, Part-Time, and Contract Employment in the United States: A Report on the W.E. Upjohn Institute's Employer Survey on Flexible Staffing Policies", June.

ILO (1997), Private Employment Agencies Convention 1997, Convention no. C181.

Kunda, Gideon, Barley, Stephen R. and Evans, James (2002), ”Why do contractors contract? The experiences of highly skilled technical professionals in a contingent labor market", Industrial and Labor Relations Review, Vol. 55, pp. 234-61. 
Miles, Thomas J. (2000), “Common Law Exceptions to Employment at Will and U.S. Labor Markets", The Journal of Law, Economics \& Organization, Vol. 16, pp. 74-101.

Milner, Joseph M. and Pinker, Edieal J. (2000), "Contingent Labor Contracting under Demand and Supply Uncertainty", The Bradley Policy Research Center Working Paper No. CIS 97-07 (revised June 2000).

SCB (1999), Registerbaserad arbetsmarknadsstatistik.

Storrie, Donald (2002), “Temporary agency work in the European Union”, European Foundation for the Improvement of Living and Working Conditions, Dublin. 


\section{Appendix}

\section{Definition of employment status}

An individual is defined as employed in the TEI in 1998 and/or 2000 if he/she

- was registered as employed in a TEA in November of the year in question.

An individual is defined as employed in another industry in 1998 and/or in 2000 if he/she

- was registered as employed in November of the respective year, and

- has not been coded as employed in a TEA during the respective year.

An individual is defined as a student in 1998 and/or in 2000 if he/she

- was registered as a student during the fall semester of the respective year,

- has not been coded as employed in the TEI during the respective year, and

- has not been coded as employed in another industry during the respective year.

An individual is defined as unemployed in 1998 and/or 2000 if he/she

- has not been coded as employed in a TEA, employed in another industry or as a student during the respective year, and

- has received unemployment insurance benefits during the year.

An individual is defined as having another employment status in 1998 and/or 2000 if he/she

- has not been coded as employed in a TEA, employed in another industry, a student or unemployed during the respective year. 
Table 1. People employed in the temporary employment industry and all employed in Sweden in November 1999; aged 16 to 64 (percent).

\begin{tabular}{l} 
Women \\
Average age \\
Age groups \\
\hline $16-20$ \\
$21-25$ \\
$26-30$ \\
$31-35$ \\
$36-40$ \\
$41-45$ \\
$46-50$ \\
$51-55$ \\
$56-60$ \\
$61-65$ \\
Born in Sweden \\
Born in another country
\end{tabular}

mployed in the TEI All employed in Sweden in November 1999 in November 1999

\begin{tabular}{l} 
The Nordic countries \\
EU12* \\
Other countries in Europe \\
Africa \\
North America \\
South America \\
Asia \\
Oceania \\
Soviet Union \\
Total \\
Born in Sweden with both parents born in another \\
country \\
Born in Sweden with one parent born in Sweden \\
and the other born in another country \\
Year of arrival (percent of immigrants) \\
\hline 1945-1965 \\
1966-1972 \\
1973-1985 \\
1986-1993 \\
1994-1999
\end{tabular}

$\begin{array}{rr}60.0 & 47.8 \\ 34.8 & 41.1 \\ & \\ 7.4 & 3.1 \\ 20.3 & 8.0 \\ 16.6 & 11.4 \\ 14.6 & 13.3 \\ 10.5 & 12.2 \\ 8.7 & 12.4 \\ 8.4 & 12.8 \\ 7.9 & 13.8 \\ 4.5 & 9.4 \\ 1.2 & 3.6 \\ 86.7 & 90.5\end{array}$

$\begin{array}{rr}3.0 & 3.4 \\ 1.0 & 1.0 \\ 2.6 & 2.0 \\ 0.9 & 0.4 \\ 0.3 & 0.2 \\ 1.2 & 0.5 \\ 4.0 & 1.9 \\ 0.0 & 0.0 \\ 0.2 & 0.1 \\ 13.4 & 9.7 \\ 4.5 & 3.0 \\ & \\ 11.2 & 10.1 \\ & \\ 6.7 & 14.2 \\ 12.8 & 17.1 \\ 31.2 & 28.6 \\ 35.3 & 25.3 \\ 14.0 & 14.8\end{array}$


Table 1 continued

Highest educational level

Primary school less than 9 years

Primary school 9 (10) years

$\begin{array}{ll}4.1 & 7.5\end{array}$

Upper secondary 2 years or less

$14.3 \quad 12.4$

Upper secondary 2 years or more

25.4

12.4

Higher education less than 3 years

29.8

31.9

Higher education 3 years or more

18.0

Higher education 3 years or more

16.2

15.5

Post-graduate education

$9.9 \quad 13.6$

Resides in a large city in 1999

$0.1 \quad 0.9$

Stockholm

$58.7 \quad 34.3$

Gothenburg

$43.0 \quad 20.2$

Malmoe

$11.6 \quad 8.6$

Marital status

\begin{tabular}{lcc}
\hline Married & 27.3 & 47.8 \\
Unmarried & 60.9 & 40.4 \\
Divorced & 11.2 & 10.6 \\
Share in TEI in 1999 & \multicolumn{2}{c}{0.5} \\
Share in manufacturing in 1999 & \multicolumn{2}{c}{80.7} \\
Share in other industries in 1999 & 18296 & \multicolumn{2}{c}{3906861} \\
\hline Number of observations
\end{tabular}

* EU12 are the fifteen EU countries with the exception of Sweden, Denmark and Finland (the two latter are included in the group Nordic Countries). 
Table 2. Marginal effects for the probability of working in a temporary employment agency in 1999. Probit models

\begin{tabular}{|c|c|c|c|}
\hline Variables & Model 1 & Model 2 & Model 3 \\
\hline Woman & $0.0015(0,00007)^{* *}$ & $0.0015(0,00007)^{* *}$ & $0.0015(0,00007)^{* *}$ \\
\hline \multicolumn{4}{|l|}{ Country of origin } \\
\hline Sweden and both parents born in Sweden & reference & reference & reference \\
\hline Born in another country than Sweden & $0.0011(0,00010)^{* *}$ & - & - \\
\hline The Nordic countries & - & $-0.0001(0,00015)$ & - \\
\hline EU & - & $0.0005(0,00030)$ & - \\
\hline Other countries in Europe & - & $0.0016(0,00024)^{* *}$ & - \\
\hline Africa & - & $0.0016(0,00043) * *$ & - \\
\hline North America & - & $0.0019(0,00070)^{* *}$ & - \\
\hline South America & - & $0.0017(0,00039)^{* *}$ & - \\
\hline Asia & - & $0.0027(0,00025)^{* *}$ & - \\
\hline Oceania & - & $-0.0025(0,00069)$ & - \\
\hline Soviet Union & - & $0.0054(0,0018)^{* *}$ & - \\
\hline $\begin{array}{l}\text { Born in Sweden and both parents born in another } \\
\text { country }\end{array}$ & $0.0008(0,00016)^{* *}$ & $0.0008(0,00016)^{* *}$ & $0.0008(0,00016)^{* *}$ \\
\hline $\begin{array}{l}\text { Born in Sweden and one of the parents born in } \\
\text { another country }\end{array}$ & $0.0006(0,00010)^{* *}$ & $0.0006(0,00010)^{* *}$ & $0.0006(0,00010) * *$ \\
\hline \multicolumn{4}{|l|}{ Year of arrival } \\
\hline $1936-1965$ & - & - & $-0.0000(0,00028)$ \\
\hline $1966-1972$ & - & - & $0.0008(0,00025)^{* *}$ \\
\hline $1973-1985$ & - & - & $0.0009(0,00017)^{* *}$ \\
\hline 1986-1993 & - & - & $0.0025(0,00022)^{* *}$ \\
\hline 1994-1999 & - & - & $0.0008(0,00025)^{* *}$ \\
\hline \multicolumn{4}{|l|}{ Highest educational level } \\
\hline Primary school less than 9 years & $-0.0002(0,00014)$ & $-0.0002(0,00014)$ & $-0.0002(0,00014)$ \\
\hline Primary school 9 (10) years & $-0.0003(0,00008)^{* *}$ & $-0.0003(0,00008) * *$ & $-0.0003(0,00008) * *$ \\
\hline Upper secondary 2 years or less & $-0.0009(0,00007)^{* *}$ & $-0.0009(0,00007)^{* *}$ & $-0.0009(0,00007) * *$ \\
\hline Upper secondary 2 years or more & reference & reference & reference \\
\hline Higher education less than 3 years & $-0.0007(0,00008)^{* *}$ & $-0.0007(0,00008) * *$ & $-0.0007(0,00008)^{* *}$ \\
\hline Higher education 3 years or more & $-0.0015(0,00007)^{* *}$ & $-0.0015(0,00007) * *$ & $-0.0015(0,00007) * *$ \\
\hline Post-graduate education & $-0.0031(0,00009)^{* *}$ & $-0.0031(0,00009) * *$ & $-0.0032(0,00009)^{* *}$ \\
\hline \multicolumn{4}{|l|}{ Region } \\
\hline Stockholm & $0.0054(0,00011)^{* *}$ & $0.0054(0,00011)^{* *}$ & $0.0054(0,00011)^{* *}$ \\
\hline Gothenburg & $0.0027(0,00015)^{* *}$ & $0.0027(0,00015)^{* *}$ & $0.0027(0,00015)^{* *}$ \\
\hline Malmoe & $0.0003(0,00013) *$ & $0.0003(0,00013)^{*}$ & $0.0003(0,00013)^{*}$ \\
\hline \multicolumn{4}{|l|}{ Age groups } \\
\hline $16-20$ years & $0.0047(0,00032)^{* *}$ & $0.0045(0,00032)^{* *}$ & $0.0046(0,00032) * *$ \\
\hline $21-25$ years & $0.0053(0,00026)^{* *}$ & $0.0051(0,00026)^{* *}$ & $0.0052(0,00026)^{* *}$ \\
\hline $26-30$ years & $0.0023(0,00017)^{* *}$ & $0.0022(0,00017)^{* *}$ & $0.0022(0,00017)^{* *}$ \\
\hline $31-35$ years & $0.0013(0,00014)^{* *}$ & $0.0013(0,00014)^{* *}$ & $0.0013(0,00014)^{* *}$ \\
\hline $36-40$ years & $0.0005(0,00013)^{* *}$ & $0.0005(0,00013)^{* *}$ & $0.0005(3.99)^{* *}$ \\
\hline $41-45$ years & reference & reference & reference \\
\hline $46-50$ years & $-0.0001(0,00012)$ & $-0.0001(0,00012)$ & $-0.0001(0,00013)$ \\
\hline $51-55$ years & $-0.0006(0,00011)^{* *}$ & $-0.0005(0,00011) * *$ & $-0.0005(0,00011)^{* *}$ \\
\hline $56-60$ years & $-0.0010(0,00011)^{* *}$ & $-0.0010(0,00011) * *$ & $-0.0010(0,00012)^{* *}$ \\
\hline $61-65$ years & $-0.0018(0,00013) * *$ & $-0.0017(0,00013) * *$ & $-0-0017(0,00014)^{* *}$ \\
\hline \multicolumn{4}{|l|}{ Marital status } \\
\hline Married & $-0.0018(0,00010)^{* *}$ & $-0.0020(0,00010)^{* *}$ & $-0.0019(0,00010)^{* *}$ \\
\hline Married woman & $0.0008(0,00013)^{* *}$ & $0.0008(0,00013)^{* *}$ & $0.0008(0,00013)^{* *}$ \\
\hline Divorced & $-0.0001(0,00015)$ & $-0.0001(0,00015)$ & $-0.0001(0,00015)$ \\
\hline Divorced woman & $0.0009(0,00022)^{* *}$ & $0.0009(0,00022)^{* *}$ & $0.0009(0,00022)^{* *}$ \\
\hline Log likelihood & $-109005,29$ & $-108935,99$ & $-108799,25$ \\
\hline Number of observations & 3862798 & 3862798 & 3854343 \\
\hline
\end{tabular}


Table 3. Employed in the Temporary Employment Industry in 1999 and all employed immigrants.

\begin{tabular}{|c|c|c|c|}
\hline & Natives & Immigrants & $\begin{array}{l}\text { All } \\
\text { immigrants } \\
\text { employed in } \\
1999\end{array}$ \\
\hline Women & 61.1 & 53.5 & 48.6 \\
\hline Average age (years) & 34.5 & 36.4 & 41.8 \\
\hline \multicolumn{4}{|l|}{ Age groups } \\
\hline $16-20$ & 7.9 & 4.4 & 1.8 \\
\hline $21-25$ & 20.9 & 16.2 & 5.9 \\
\hline $26-30$ & 16.8 & 14.9 & 9.8 \\
\hline $31-35$ & 14.4 & 15.9 & 13.7 \\
\hline $36-40$ & 10.1 & 12.7 & 14.9 \\
\hline $41-45$ & 8.3 & 11.5 & 14.8 \\
\hline $46-50$ & 8.0 & 10.8 & 14.0 \\
\hline $51-55$ & 7.9 & 7.8 & 12.7 \\
\hline $56-60$ & 4.6 & 4.3 & 8.7 \\
\hline $61-65$ & 1.1 & 1.5 & 3.6 \\
\hline \multicolumn{4}{|l|}{ Highest educational level } \\
\hline Primary school less than 9 years & 3.3 & 6.5 & 11.0 \\
\hline Primary school $9(10)$ years & 11.0 & 10.2 & 13.4 \\
\hline Upper secondary 2 years or less & 26.5 & 24.6 & 25.8 \\
\hline Upper secondary 2 years or more & 31.7 & 28.4 & 18.2 \\
\hline Higher education less than 3 years & 13.5 & 14.7 & 13.2 \\
\hline Higher education 3 years or more & 13.7 & 14.5 & 14.2 \\
\hline Post-graduate education & 0.0 & 0.3 & 1.6 \\
\hline Resides in a large city in 1999 & 57.8 & 63.9 & 54.9 \\
\hline Stockholm & 42.2 & 48.1 & 36.3 \\
\hline Gothenburg & 11.4 & 12.6 & 10.3 \\
\hline Malmoe & 4.2 & 3.2 & 8.3 \\
\hline \multicolumn{4}{|l|}{ Marital status } \\
\hline Married & 25.3 & 41.0 & 55.2 \\
\hline Unmarried & 63.7 & 42.3 & 27.1 \\
\hline Divorced & 10.5 & 15.7 & \\
\hline \multicolumn{4}{|l|}{ Employment status in November 1998} \\
\hline Temporary Employment Agency & 39.7 & 34.3 & \\
\hline Employed in another industry & 36.7 & 30.0 & \\
\hline Student & 11.4 & 15.9 & \\
\hline Unemployed & 5.6 & 8.9 & \\
\hline Other status & 6.5 & 10.8 & \\
\hline \multicolumn{4}{|l|}{ Employment status in November 2000} \\
\hline Temporary Employment Agency & 42.6 & 38.1 & \\
\hline Employed in another industry & 48.7 & 52.4 & \\
\hline Student & 5.6 & 2.7 & \\
\hline Unemployed & 1.7 & 2.6 & \\
\hline Other status & 3.7 & 4.1 & \\
\hline
\end{tabular}


Born in Sweden with parents born in another country

Born in Sweden with one parent born in another country

Born in another country

The Nordic countries

EU12

Other countries in Europe

Africa

North America

South America

Asia

Oceania

Soviet Union

Year of arrival

1945-1965

1966-1972

1973-1985

1986-1993

1994-1999

Number of observations
5.2

7.8

$\begin{array}{cc}23.0 & 35.7 \\ 7.7 & 10.6 \\ 20.0 & 21.1 \\ 6.7 & 4.6 \\ 2.6 & 2.3 \\ 8.8 & 5.5 \\ 29.9 & 19.3 \\ 0.1 & 0.3 \\ 1.2 & 0.6\end{array}$

6.6

14.6

12.6

30.9

17.5

29.3

25.8

12.7

379631 
Table 4. Descriptive statistics for immigrants from different regions

\begin{tabular}{|c|c|c|c|c|}
\hline & NORTH & WEST & EAST & SOUTH \\
\hline Women & 72.6 & 54.7 & 56.2 & 42.2 \\
\hline Average age (years) & 42.8 & 37.9 & 36.6 & 32.8 \\
\hline \multicolumn{5}{|l|}{ Age groups } \\
\hline $16-20$ & 0.4 & 0.8 & 5.0 & 7.1 \\
\hline $21-25$ & 5.5 & 13.4 & 14.5 & 23.1 \\
\hline $26-30$ & 7.5 & 15.7 & 15.1 & 18.5 \\
\hline $31-35$ & 15.3 & 20.9 & 13.5 & 16.1 \\
\hline $36-40$ & 12.2 & 13.0 & 15.3 & 11.7 \\
\hline $41-45$ & 13.3 & 8.3 & 13.9 & 10.1 \\
\hline $46-50$ & 19.9 & 9.0 & 11.4 & 6.3 \\
\hline $51-55$ & 16.3 & 9.0 & 5.8 & 4.1 \\
\hline $56-60$ & 6.9 & 8.3 & 4.4 & 2.0 \\
\hline $61-65$ & 2.7 & 1.6 & 1.1 & 1.0 \\
\hline \multicolumn{5}{|l|}{ Highest educational level } \\
\hline Primary school less than 9 years & 9.4 & 4.3 & 4.6 & 8.5 \\
\hline Primary school 9 (10) years & 13.8 & 13.0 & 8.3 & 16.6 \\
\hline Upper secondary 2 years or less & 33.4 & 20.1 & 19.1 & 17.8 \\
\hline Upper secondary 2 years or more & 16.9 & 25.2 & 32.4 & 31.1 \\
\hline Higher education less than 3 years & 14.9 & 18.5 & 16.8 & 15.5 \\
\hline Higher education 3 years or more & 11.0 & 15.8 & 17.8 & 9.0 \\
\hline Post-graduate education & 0.0 & 1.2 & 0.4 & 0.3 \\
\hline Resides in a large city in 1999 & 62.2 & 65.4 & 62.4 & 65.1 \\
\hline Stockholm & 50.1 & 45.3 & 44.6 & 49.5 \\
\hline Gothenburg & 8.5 & 14.2 & 12.4 & 14.3 \\
\hline Malmoe & 3.6 & 5.9 & 5.4 & 1.3 \\
\hline \multicolumn{5}{|l|}{ Marital status } \\
\hline Married & 37.3 & 42.9 & 49.6 & 38.2 \\
\hline Unmarried & 41.7 & 43.3 & 33.0 & 49.6 \\
\hline Divorced & 18.7 & 13.0 & 17.2 & 11.9 \\
\hline \multicolumn{5}{|l|}{ Employment status in November 1998} \\
\hline Temporary Employment Agency & 47.4 & 37.0 & 29.8 & 28.1 \\
\hline Employed in another industry & 28.8 & 31.5 & 27.0 & 29.5 \\
\hline Student & 12.3 & 9.8 & 7.4 & 20 \\
\hline Unemployed & 11.5 & 12.2 & 20.8 & 10.6 \\
\hline Other status & 5.7 & 9.5 & 15.0 & 11.8 \\
\hline \multicolumn{5}{|l|}{ Employment status in November 2000} \\
\hline Temporary Employment Agency & 47.6 & 44.0 & 34.0 & 33.9 \\
\hline Employed in another industry & 45.5 & 47.6 & 57.1 & 54.9 \\
\hline Student & 0.7 & 2.4 & 2.2 & 3.6 \\
\hline Unemployed & 2.1 & 2.8 & 2.9 & 3.1 \\
\hline Other status & 4.1 & 3.2 & 3.8 & 4.5 \\
\hline \multicolumn{5}{|l|}{ Born in another country } \\
\hline Nordic countries & 100.0 & $*$ & $*$ & $*$ \\
\hline EU12 & $*$ & 74.0 & $*$ & $*$ \\
\hline
\end{tabular}




\begin{tabular}{lcccc} 
Other countries in Europe & $*$ & $*$ & 94.4 & $*$ \\
Africa & $*$ & $*$ & $*$ & 14.8 \\
North America & $*$ & 25.2 & $*$ & $*$ \\
South America & $*$ & $*$ & $*$ & 19.4 \\
Asia & $*$ & $*$ & $*$ & 65.8 \\
Oceania & $*$ & 0.8 & $*$ & $*$ \\
Soviet Union & $*$ & $*$ & 5.6 & $*$ \\
Year of arrival & & & & \\
1945-1965 & 21.6 & 11.6 & 2.3 & 0.2 \\
$1966-1972$ & 30.0 & 13.8 & 9.8 & 5.0 \\
$1973-1985$ & 25.8 & 33.1 & 20.3 & 37.9 \\
$1986-1993$ & 11.5 & 20.9 & 38.6 & 48.1 \\
$1994-1999$ & 9.2 & 19.7 & 27.4 & 8.5 \\
Sum & 98.1 & 99.1 & 98.4 & 99.7 \\
\hline Number of observations & 563 & 254 & 518 & 1113 \\
\hline
\end{tabular}


Table 5. Flows between different states

\begin{tabular}{|c|c|c|c|c|c|c|}
\hline \multirow{2}{*}{$\begin{array}{l}\mathbf{A L L} \\
1998\end{array}$} & \multicolumn{6}{|c|}{2000} \\
\hline & TEA & $\begin{array}{l}\text { Employed in } \\
\text { another industry }\end{array}$ & Unemployed & Student & $\begin{array}{l}\text { Other } \\
\text { status }\end{array}$ & Sum \\
\hline TEA & $21.8 \%$ & $14.7 \%$ & $0.3 \%$ & $0.7 \%$ & $1.5 \%$ & $39.0 \%$ \\
\hline $\begin{array}{l}\text { Employed in another } \\
\text { industry }\end{array}$ & $12.6 \%$ & $20.6 \%$ & $0.7 \%$ & $1.0 \%$ & $0.9 \%$ & $35.8 \%$ \\
\hline Unemployed & $2.2 \%$ & $3.1 \%$ & $0.4 \%$ & $0.1 \%$ & $0.2 \%$ & $6.0 \%$ \\
\hline Student & $3.2 \%$ & $7.1 \%$ & $0.2 \%$ & $1.0 \%$ & $0.6 \%$ & $12.1 \%$ \\
\hline Other status & $2.3 \%$ & $3.8 \%$ & $0.2 \%$ & $0.3 \%$ & $0.5 \%$ & $7.1 \%$ \\
\hline Sum & $42.1 \%$ & $49.3 \%$ & $1.8 \%$ & $3.1 \%$ & $3.7 \%$ & $100.0 \%$ \\
\hline \multicolumn{7}{|l|}{ N: 18296} \\
\hline NATIVES & \multicolumn{6}{|c|}{2000} \\
\hline 1998 & TEA & $\begin{array}{l}\text { Employed in } \\
\text { another industry }\end{array}$ & Unemployed & Student & $\begin{array}{l}\text { Other } \\
\text { status }\end{array}$ & Sum \\
\hline TEA & $22.3 \%$ & $14.9 \%$ & $0.3 \%$ & $0.8 \%$ & $1.4 \%$ & $39.7 \%$ \\
\hline $\begin{array}{l}\text { Employed in another } \\
\text { industry }\end{array}$ & $13.1 \%$ & $20.8 \%$ & $0.7 \%$ & $1.1 \%$ & $1.0 \%$ & $36.7 \%$ \\
\hline Unemployed & $2.1 \%$ & $2.8 \%$ & $0.4 \%$ & $0.1 \%$ & $0.2 \%$ & $5.6 \%$ \\
\hline Student & $3.0 \%$ & $6.8 \%$ & $0.2 \%$ & $0.9 \%$ & $0.6 \%$ & $11.5 \%$ \\
\hline Other Status & $2.2 \%$ & $3.4 \%$ & $0.1 \%$ & $0.3 \%$ & $0.5 \%$ & $6.5 \%$ \\
\hline Sum & $42.7 \%$ & $48.7 \%$ & $1.7 \%$ & $3.2 \%$ & $3.7 \%$ & $100.0 \%$ \\
\hline \multicolumn{7}{|l|}{$\mathrm{N}: 15847$} \\
\hline IMMIGRANTS & \multicolumn{6}{|c|}{2000} \\
\hline 1998 & TEA & $\begin{array}{l}\text { Employed in } \\
\text { another industry }\end{array}$ & Unemployed & Student & $\begin{array}{l}\text { Other } \\
\text { status }\end{array}$ & Sum \\
\hline TEA & $18.5 \%$ & $13.3 \%$ & $0.4 \%$ & $0.5 \%$ & $1.7 \%$ & $34.4 \%$ \\
\hline $\begin{array}{l}\text { Employed in another } \\
\text { industry }\end{array}$ & $9.1 \%$ & $19.1 \%$ & $0.8 \%$ & $0.3 \%$ & $0.7 \%$ & $30.0 \%$ \\
\hline Unemployed & $3.2 \%$ & $4.8 \%$ & $0.6 \%$ & $0.1 \%$ & $0.2 \%$ & $8.9 \%$ \\
\hline Student & $4.3 \%$ & $9.1 \%$ & $0.2 \%$ & $1.6 \%$ & $0.7 \%$ & $15.9 \%$ \\
\hline Other Status & $3.1 \%$ & $6.1 \%$ & $0.6 \%$ & $0.2 \%$ & $0.8 \%$ & $10.8 \%$ \\
\hline Sum & $38.2 \%$ & $52.4 \%$ & $2.6 \%$ & $2.7 \%$ & $4.1 \%$ & $100.0 \%$ \\
\hline $\mathrm{N}: 2449$ & & & & & & \\
\hline
\end{tabular}


Table 6. Flows between different states for different groups of immigrants

\begin{tabular}{|c|c|c|c|c|c|c|}
\hline NORTH & & & 2000 & & & \\
\hline 1998 & TEA & $\begin{array}{c}\text { Employed in } \\
\text { another industry }\end{array}$ & Unemployed & Student & $\begin{array}{l}\text { Other } \\
\text { status }\end{array}$ & Sum \\
\hline TEA & $29.7 \%$ & $16.9 \%$ & $0.3 \%$ & $0.3 \%$ & $2.3 \%$ & $49.5 \%$ \\
\hline $\begin{array}{l}\text { Employed in another } \\
\text { Industry }\end{array}$ & $12.6 \%$ & $18.1 \%$ & $1.2 \%$ & $0.4 \%$ & $0.9 \%$ & $33.2 \%$ \\
\hline Unemployed & $2.5 \%$ & $3.6 \%$ & $0.3 \%$ & $0.0 \%$ & $0.2 \%$ & $6.6 \%$ \\
\hline Student & $1.2 \%$ & $3.4 \%$ & $0.0 \%$ & $0.0 \%$ & $0.4 \%$ & $5.0 \%$ \\
\hline Other Status & $1.6 \%$ & $3.6 \%$ & $0.2 \%$ & $0.0 \%$ & $0.3 \%$ & $5.7 \%$ \\
\hline Sum & & $45.6 \%$ & $2.0 \%$ & $0.7 \%$ & $4.1 \%$ & $100.0 \%$ \\
\hline $\mathrm{N}: 563$ & & & & & & \\
\hline WEST & & & & & & \\
\hline 1998 & TEA & $\begin{array}{c}\text { Employed in } \\
\text { another industry }\end{array}$ & Unemployed & Student & $\begin{array}{l}\text { Other } \\
\text { status }\end{array}$ & Sum \\
\hline TEA & $23.6 \%$ & $11.0 \%$ & $0.0 \%$ & $0.4 \%$ & $2.0 \%$ & $37.0 \%$ \\
\hline $\begin{array}{l}\text { Employed in another } \\
\text { Industry }\end{array}$ & $10.6 \%$ & $18.9 \%$ & $1.2 \%$ & $0.4 \%$ & $0.4 \%$ & $31.5 \%$ \\
\hline Unemployed & $2.7 \%$ & $5.9 \%$ & $0.8 \%$ & $0.0 \%$ & $0.4 \%$ & $9.8 \%$ \\
\hline Student & $4.3 \%$ & $6.7 \%$ & $0.0 \%$ & $1.2 \%$ & $0.0 \%$ & $12.2 \%$ \\
\hline Other Status & $2.8 \%$ & $5.1 \%$ & $0.4 \%$ & $0.8 \%$ & $0.4 \%$ & $9.5 \%$ \\
\hline Sum & $44.0 \%$ & $47.6 \%$ & $2.4 \%$ & $2.8 \%$ & $3.2 \%$ & $100.0 \%$ \\
\hline
\end{tabular}

\section{EAST}

\begin{tabular}{|c|c|c|c|c|c|c|}
\hline 1998 & TEA & $\begin{array}{c}\text { Employed in } \\
\text { another industry }\end{array}$ & Unemployed & Student & $\begin{array}{l}\text { Other } \\
\text { status }\end{array}$ & Sum \\
\hline TEA & $11.8 \%$ & $14.5 \%$ & $0.4 \%$ & $0.6 \%$ & $2.5 \%$ & $29.8 \%$ \\
\hline $\begin{array}{l}\text { Employed in another } \\
\text { Industry }\end{array}$ & $8.3 \%$ & $17.9 \%$ & $0.2 \%$ & $0.2 \%$ & $0.4 \%$ & $27.0 \%$ \\
\hline Unemployed & $3.1 \%$ & $3.9 \%$ & $0.4 \%$ & $0.0 \%$ & $0.0 \%$ & $7.4 \%$ \\
\hline Student & $6.0 \%$ & $12.3 \%$ & $0.6 \%$ & $1.9 \%$ & $0.0 \%$ & $20.8 \%$ \\
\hline Other Status & $4.8 \%$ & $8.5 \%$ & $0.6 \%$ & $0.2 \%$ & $0.9 \%$ & $15.0 \%$ \\
\hline Sum & $34.0 \%$ & $57.1 \%$ & $2.2 \%$ & $2.9 \%$ & $3.8 \%$ & $100.0 \%$ \\
\hline
\end{tabular}

\begin{tabular}{|c|c|c|c|c|c|c|}
\hline SOUTH & & & & & & \\
\hline 1998 & TEA & $\begin{array}{c}\text { Employed in } \\
\text { another industry }\end{array}$ & Unemployed & Student & $\begin{array}{l}\text { Other } \\
\text { status }\end{array}$ & Sum \\
\hline TEA & $14.7 \%$ & $11.6 \%$ & $0.4 \%$ & $0.4 \%$ & $0.9 \%$ & $28.0 \%$ \\
\hline $\begin{array}{l}\text { Employed in another } \\
\text { Industry }\end{array}$ & $7.3 \%$ & $20.1 \%$ & $0.8 \%$ & $0.4 \%$ & $0.9 \%$ & $29.5 \%$ \\
\hline Unemployed & $3.7 \%$ & $5.7 \%$ & $0.8 \%$ & $0.2 \%$ & $0.3 \%$ & $10.7 \%$ \\
\hline Student & $5.1 \%$ & $11.1 \%$ & $0.2 \%$ & $2.3 \%$ & $1.3 \%$ & $20.0 \%$ \\
\hline Other Status & $3.0 \%$ & $6.5 \%$ & $0.9 \%$ & $0.3 \%$ & $1.1 \%$ & $11.8 \%$ \\
\hline Sum & $33.8 \%$ & $55.0 \%$ & $3.1 \%$ & $3.6 \%$ & $4.5 \%$ & $100.0 \%$ \\
\hline
\end{tabular}


Table 7. Marginal effects for the probability of individuals who were unemployed in 1999 to work in a TEA in 2000. Standard errors in parentheses

Variables

Female

$-0.0007(0.0002) * * *$

Place of birth

Sweden

North

West

East

South

Second generation immigrant
16-20
21-25
26-30
31-35
$36-40$
41-45
46-50
$51-55$
56-60
$61-65$

Age groups

Highest Educational Level

Primary school less than 9 years

Primary school 9 (10) years

Upper secondary 2 years or less

Upper secondary 2 years or more

Higher education less than 3 years

Higher education 3 years or more

Post-graduate education

Marital status

Unmarried

Married

Divorced

Stockholm

Gothenburg

Malmoe

Number of observations reference

$$
-0.0007(0.0005)
$$

$0.0014(0.0010)$

$-0.0005(0.0005)$

$-0.0002(0.0003)$

$0.0020(0.0007)^{* * *}$

$$
\begin{gathered}
0.0057(0.0020)^{* * *} \\
0.0026(0.0007) * * * \\
0.0009(0.0005)^{*} \\
0.0007(0.0005) \\
-0.0002(0.0004) \\
\text { reference } \\
-0.0001(0.0005) \\
-0.0008(0.0004)^{*} \\
-0.0026(0.0003)^{* * *} \\
-0.0045(0.0002)^{* * *}
\end{gathered}
$$

$$
\begin{gathered}
-0.0022(0.00047)^{* * *} \\
-0.0010(0.0003)^{* * *} \\
-0.0070(0.0003)^{* *} \\
0.0005(0.0004) \\
\text { reference } \\
-0.0005(0.0005) \\
-0.0002(0.0019)
\end{gathered}
$$

$$
\text { reference }
$$

-0.0003 (0.0003)

$-0.0002(0.0003)$

$0.0052(0.0006)^{* *}$

$0.0024(0.0005) * * *$ $0.0001(0.0005)$ 
Table 8. Multinomial logit. Probability for having a certain employment status in 1998 for individuals who were employed in the TEI in 1999. Standard errors in parentheses.

\begin{tabular}{|c|c|c|c|c|c|}
\hline Variables & $\begin{array}{l}\text { TEA } \\
\text { (comparison } \\
\text { group) }\end{array}$ & $\begin{array}{l}\text { Employed in } \\
\text { another industry }\end{array}$ & Student & Unemployed & Other status \\
\hline Female & & $0.0593(0.375)$ & $-0.1128(0.0568)^{* *}$ & $-0.4931(0.0681)^{* * *}$ & $-0.4618(0.0652)^{* * *}$ \\
\hline \multicolumn{6}{|l|}{ Place of birth } \\
\hline Sweden & & reference & reference & reference & reference \\
\hline North & & $-0.0810(0.0981)$ & $0.0054(0.2125)$ & $0.1520(0.1819)$ & $0.3881(0.1954)^{* *}$ \\
\hline West & & $0.0568(0.1555)$ & $0.7220(0.2275)^{* * *}$ & $0.7171(0.2326)^{* * *}$ & $0.8102(0.2393)^{* * *}$ \\
\hline East & & $0.0935(0.1203)$ & $1.5217(0.1455)^{* * *}$ & $0.6833(0.1894)^{* * *}$ & $1.4680(0.1523)^{* * *}$ \\
\hline South & & $0.1384(0.0837)^{*}$ & $1.0804(0.1042)^{* * *}$ & $0.9472(0.1195)^{* * *}$ & $0.8968(0.1168)^{* * *}$ \\
\hline $\begin{array}{l}\text { Second generation } \\
\text { immigrant }\end{array}$ & & $0.0804(0.0866)$ & $0.0079(0.1312)$ & $0.1323(0.1655)$ & $0.4201(0.1334)^{* * *}$ \\
\hline \multicolumn{6}{|l|}{ Age groups } \\
\hline $16-20$ & & $1.5379(0.1228) * * *$ & $4.4043(0.1734)^{* * *}$ & $-41.6738(2.59 \mathrm{e}+08)$ & $2.9552(0.1857)^{* * *}$ \\
\hline $21-25$ & & $0.7039(0.0776) * * *$ & $2.1471(0.1447)^{* * *}$ & $0.2702(0.1470)^{*}$ & $1.6963(0.1533)^{* * *}$ \\
\hline $26-30$ & & $0.4045(0.0763) * * *$ & $1.3959(0.1414)^{* * *}$ & $0.5628(0.1337)^{* * *}$ & $0.8743(0.1540)^{* * *}$ \\
\hline $31-35$ & & $0.0857(0.0716)$ & $0.5638(0.1461)^{* * *}$ & $0.2458(0.1320)^{*}$ & $0.3340(0.1563)^{* *}$ \\
\hline $36-40$ & & $0.0349(0.0763)$ & $0.3865(0.1566)^{* *}$ & $0.4209(0.1349)^{* * *}$ & $0.2639(0.1657)$ \\
\hline $41-45$ & & reference & reference & reference & reference \\
\hline $46-50$ & & $-0.1398 *(0.0796)$ & $\begin{array}{l}-0.6754 \\
(0.2035)^{* * *}\end{array}$ & $-0.0237(0.1493)$ & $-0.0487(0.1791)$ \\
\hline $51-55$ & & $-0.0847(0.0811)$ & $\begin{array}{l}-1.2308 \\
(0.2652)^{* * *}\end{array}$ & $0.0415(0.1531)$ & $-0.4812(0.2093)^{* *}$ \\
\hline $56-60$ & & $\begin{array}{l}-0.3789 \\
(0.0975)^{* * *}\end{array}$ & $\begin{array}{l}-3.7874 \\
(1.0103)^{* * *}\end{array}$ & $-0.7174(0.2182)^{* * *}$ & $-0.6743(0.2572) * * *$ \\
\hline $61-65$ & & $\begin{array}{l}-0.5016 \\
(0.1624) * * *\end{array}$ & $\begin{array}{l}-41.4089 \\
(2.77 \mathrm{e}+08)\end{array}$ & $-2.9738(1.0110) * * *$ & $-1.2113(0.5291)^{* *}$ \\
\hline \multicolumn{6}{|l|}{ Highest } \\
\hline $\begin{array}{l}\text { Primary school less } \\
\text { than } 9 \text { years }\end{array}$ & & $-0.1159(0.0974)$ & $0.0841(0.2895)$ & $-0.3988(0.1955)^{*}$ & $-0.2957(0.2322)$ \\
\hline $\begin{array}{l}\text { Primary school } 9 \\
\text { (10) years }\end{array}$ & & $\begin{array}{l}-0.2709 \\
(0.0604) * * *\end{array}$ & $0.2366(0.0894)^{* * *}$ & $0.0871(0.1060)$ & $0.1800(0.0921)^{*}$ \\
\hline $\begin{array}{l}\text { Upper secondary } 2 \\
\text { years or less }\end{array}$ & & $-0.0564(0.0516)$ & $0.3106(0.0924)^{* * *}$ & $0.1136(0.0932)$ & $-0.1636(0.0976)^{*}$ \\
\hline $\begin{array}{l}\text { Upper secondary } 2 \\
\text { years or more }\end{array}$ & & reference & reference & reference & reference \\
\hline $\begin{array}{l}\text { Higher education } \\
\text { less than } 3 \text { years }\end{array}$ & & $0.1793(0.0581)^{* * *}$ & $1.5410(0.0821)^{* * *}$ & $-0.2247(0.1199)^{*}$ & $-0.0027(0.1074)$ \\
\hline $\begin{array}{l}\text { Higher education } 3 \\
\text { years or more }\end{array}$ & & $-0.0523(0.0659)$ & $\begin{array}{l}0.54431 \\
(0.1160)^{* * *}\end{array}$ & $-0.5032(0.1398) * * *$ & $-0.3275(0.1384)^{* *}$ \\
\hline $\begin{array}{l}\text { Post-graduate } \\
\text { education }\end{array}$ & & $-0.7040(0.8222)$ & $1.2736(1.1221)$ & $0.6794(0.8627)$ & $1.3334(0.7494)^{*}$ \\
\hline \multicolumn{6}{|l|}{ Marital status } \\
\hline Unmarried & & reference & reference & reference & reference \\
\hline Married & & $0.0088(0.0461)$ & $-0.2170(0.0869)^{* *}$ & $-0.1034(0.0848)$ & $0.1418(0.0939)$ \\
\hline
\end{tabular}




\begin{tabular}{lllll} 
Divorced & $0.1459(0.0613)^{* *}$ & $0.0674(0.1293)$ & $-0.0043(0.1141)$ & $0.1563(0.1345)$ \\
& & & & \\
Stockholm & $-0.0209(0.0396)$ & $-0.1193(0.0612)^{*}$ & $-0.4001(0.7049)^{* * *}$ & $0.0397(0.0708)$ \\
Gothenburg & $0.3573(0.0591)^{* * *}$ & $0.2363(0.0901)^{* * *}$ & $-0.0860(0.1127)$ & $0.3279(0.1031)^{* * *}$ \\
Malmoe & $0.0355(0.0931)$ & $0.1793(0.1333)$ & $0.0742(0.1666)$ & $0.2033(0.1624)$ \\
Constant & -0.3628 & -2.9200 & $-1.6365(0.1428)^{* * *}$ & $-2.4430(0.1594)^{* * *}$ \\
& $(0.0783)^{* * *}$ & $(0.1531)^{* * *}$ & & \\
\hline
\end{tabular}

$\mathrm{N}$ 18296

*** significant on the $1 \%$ level, ** significant on the $5 \%$ level, * significant on the $10 \%$ level

North: The Nordic countries

Soviet Union

West: European Union, North America and Oceania
East: Europe (except EU and the Nordic countries) and

South: Africa, Asia and South America 
Table 9. Multinomial logit. Probabilities of having a certain employment status in 2000 for individuals who were employed in the TEI in 1999. Standard errors in parentheses

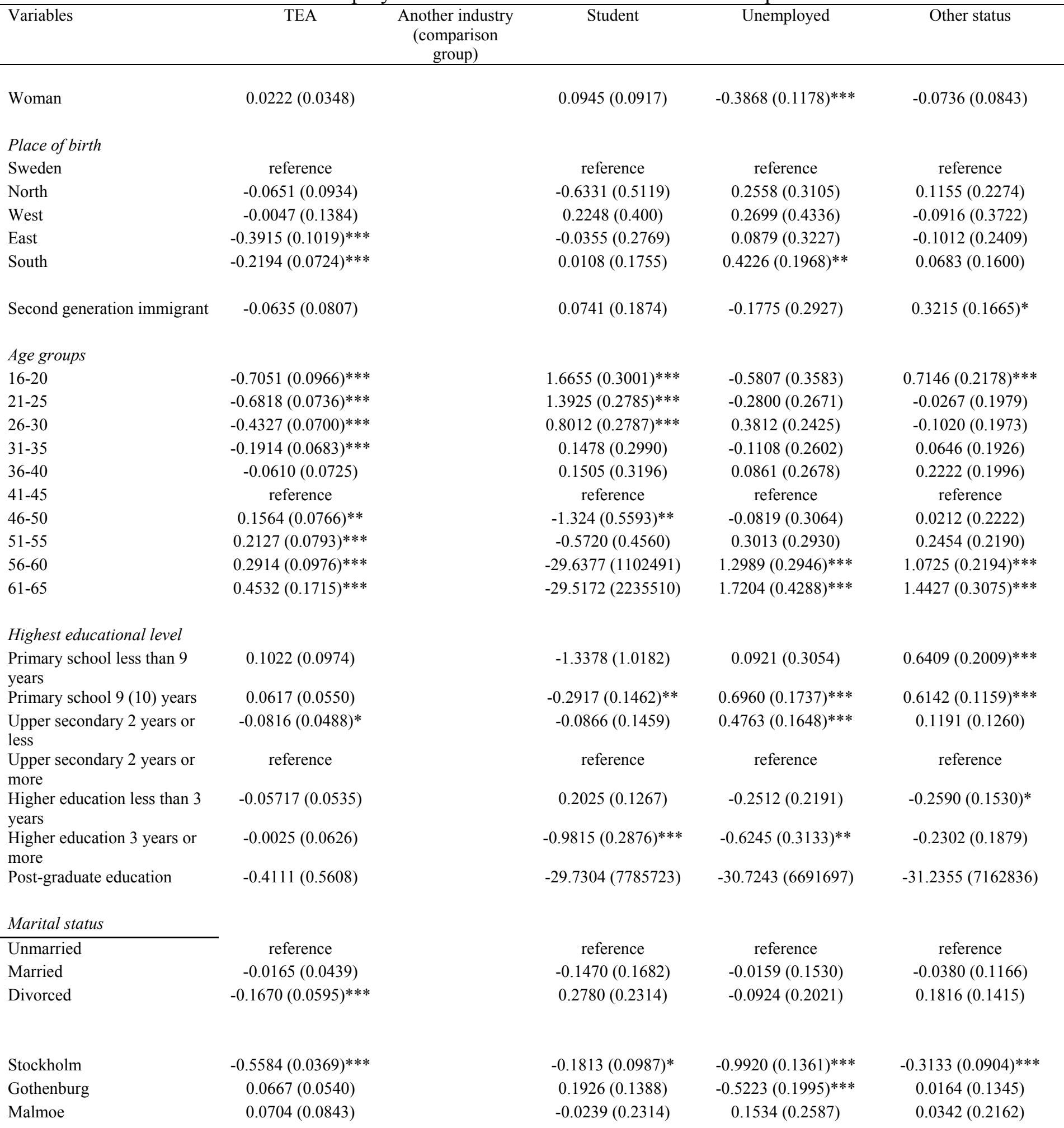


TEA

Employed in another Industry

Unemployed

Student

Other status reference

$-0.8081(0.0377)^{* * * *}$

$-0.7068(0.0715) * * *$

$-0.8701(0.0614) * * *$

$-0.6394(0.0701)^{* * *}$ reference

$-0.3633(0.1179)$

$-0.6532(0.2710)^{* *}$

$0.2331(0.1302)^{*}$

$-0.1998(0.1730)$ reference $0.7687(0.1664)^{* * *}$

$1.1811(0.1905) * * *$

$0.6238(0.2435) * * *$

$1.2684(0.2255) * * *$ reference $-0.7565(0.1033) * * *$

$-0.3301(0.1080)^{*}$

$-0.2026(0.1377)$

$0.3482(0.1345)^{* * *}$ 
Table 10. Descriptive statistics for those who worked in the TEI in all three years

\begin{tabular}{|c|c|c|c|}
\hline & All & $\begin{array}{l}\text { Born in } \\
\text { Sweden }\end{array}$ & $\begin{array}{l}\text { Born } \\
\text { outside } \\
\text { of Sweden }\end{array}$ \\
\hline Women & 60.6 & 60.7 & 59.2 \\
\hline Average age (years) & 40.7 & 40.5 & 42.3 \\
\hline \multicolumn{4}{|l|}{ Age groups } \\
\hline $16-20$ & 1.0 & 1.1 & 0.4 \\
\hline $21-25$ & 8.9 & 9.3 & 6.0 \\
\hline $26-30$ & 12.0 & 12.1 & 10.8 \\
\hline $31-35$ & 15.6 & 16.1 & 11.2 \\
\hline $36-40$ & 12.6 & 12.3 & 14.6 \\
\hline $41-45$ & 12.0 & 11.4 & 16.3 \\
\hline $46-50$ & 13.6 & 13.5 & 14.6 \\
\hline $51-55$ & 12.9 & 12.9 & 12.8 \\
\hline $56-60$ & 8.8 & 8.5 & 10.4 \\
\hline $61-65$ & 2.6 & 2.5 & 2.9 \\
\hline \multicolumn{4}{|l|}{ Highest educational level } \\
\hline $\begin{array}{l}\text { Primary school less than } 9 \\
\text { years }\end{array}$ & 8.2 & 7.7 & 11.9 \\
\hline Primary school 9 (10) years & 15.6 & 15.8 & 13.9 \\
\hline $\begin{array}{l}\text { Upper secondary } 2 \text { years or } \\
\text { less }\end{array}$ & 31.0 & 31.7 & 24.9 \\
\hline $\begin{array}{l}\text { Upper secondary } 2 \text { years or } \\
\text { more }\end{array}$ & 20.3 & 19.8 & 23.6 \\
\hline $\begin{array}{l}\text { Higher education less than } 3 \\
\text { years }\end{array}$ & 12.9 & 13.1 & 11.5 \\
\hline $\begin{array}{l}\text { Higher education } 3 \text { years or } \\
\text { more }\end{array}$ & 11.6 & 11.5 & 13.0 \\
\hline Post-graduate education & 0.1 & 0.1 & 0.2 \\
\hline Resides in a large city in 1999 & 49.0 & 48.7 & 53.0 \\
\hline Stockholm & 33.7 & 33.7 & 33.7 \\
\hline Gothenburg & 10.9 & 10.5 & 15.2 \\
\hline Malmoe & 4.4 & 4.5 & 4.1 \\
\hline \multicolumn{4}{|l|}{ Marital status } \\
\hline Married & 35.5 & 33.7 & 49.9 \\
\hline Unmarried & 49.4 & 52.0 & 28.7 \\
\hline Divorced & 13.8 & 13.1 & 20.0 \\
\hline Country of origin & & & \\
\hline & 3.4 & 3.8 & \\
\hline \multicolumn{4}{|l|}{$\begin{array}{l}\text { Born in Sweden with both } \\
\text { parents born in another } \\
\text { country }\end{array}$} \\
\hline Born in Sweden with one & 12.1 & 13.6 & \\
\hline
\end{tabular}


parent born in another country

Born in another country

\begin{tabular}{lcc} 
The Nordic countries & 4.2 & 36.9 \\
EU12 & 1.2 & 10.6 \\
Other countries in Europe & 0.3 & 12.8 \\
Africa & 0.8 & 2.6 \\
North America & 0.6 & 6.8 \\
South America & 2.7 & 4.8 \\
Asia & 0.0 & 23.8 \\
Oceania & 0.0 & 0.0 \\
Soviet Union & & 0.7 \\
Year of arrival & & \\
1945-1965 & & 10.8 \\
1966-1972 & & 33.6 \\
1973-1985 & & 29.8 \\
1986-1993 & & 4.6 \\
1994-1999 & & 453 \\
\hline Number of observations & 3984 & \\
\hline
\end{tabular}


Table 11. Descriptive statistics for those who were unemployed in 1998, worked in a TEA in 1999 and were employed in another industry in 2000

\begin{tabular}{|c|c|c|c|}
\hline & All & $\begin{array}{l}\text { Born in } \\
\text { Sweden }\end{array}$ & $\begin{array}{l}\text { Born in another } \\
\text { country }\end{array}$ \\
\hline Women & 47.2 & 49.7 & 38.1 \\
\hline Average age (years) & 35.1 & 34.4 & 37.5 \\
\hline \multicolumn{4}{|l|}{ Age groups } \\
\hline $16-20$ & 0.0 & 0.0 & 0.0 \\
\hline $21-25$ & 16.9 & 18.9 & 9.3 \\
\hline $26-30$ & 22.0 & 23.8 & 15.2 \\
\hline $31-35$ & 20.2 & 20.0 & 21.2 \\
\hline $36-40$ & 14.2 & 12.4 & 21.2 \\
\hline $41-45$ & 8.9 & 8.8 & 9.3 \\
\hline $46-50$ & 7.6 & 6.7 & 11.0 \\
\hline $51-55$ & 7.3 & 6.3 & 11.0 \\
\hline $56-60$ & 2.7 & 2.9 & 1.7 \\
\hline $61-65$ & 0.2 & 0.2 & 0.0 \\
\hline \multicolumn{4}{|l|}{ Highest educational level } \\
\hline $\begin{array}{l}\text { Primary school less than } 9 \\
\text { years }\end{array}$ & 2.3 & 1.3 & 5.9 \\
\hline Primary school 9 (10) years & 13.1 & 13.9 & 10.2 \\
\hline $\begin{array}{l}\text { Upper secondary } 2 \text { years or } \\
\text { less }\end{array}$ & 34.3 & 35.7 & 28.8 \\
\hline $\begin{array}{l}\text { Upper secondary } 2 \text { years or } \\
\text { more }\end{array}$ & 27.8 & 29.0 & 22.9 \\
\hline $\begin{array}{l}\text { Higher education less than } 3 \\
\text { years }\end{array}$ & 13.8 & 12.8 & 17.8 \\
\hline $\begin{array}{l}\text { Higher education } 3 \text { years or } \\
\text { more }\end{array}$ & 8.3 & 7.2 & 12.7 \\
\hline Post-graduate education & 0.3 & 0.0 & 1.7 \\
\hline $\begin{array}{l}\text { Resides in a large city in } \\
1999\end{array}$ & 50.6 & 55.3 & 57.6 \\
\hline Stockholm & 37.6 & 39.5 & 48.3 \\
\hline Gothenburg & 9.1 & 11.6 & 5.1 \\
\hline Malmoe & 3.9 & 4.2 & 4.2 \\
\hline \multicolumn{4}{|l|}{ Marital status } \\
\hline Married & 28.2 & 22.9 & 48.3 \\
\hline Unmarried & 59.7 & 66.5 & 33.9 \\
\hline $\begin{array}{l}\text { Divorced } \\
\text { Country of origin }\end{array}$ & 11.5 & 9.9 & 17.8 \\
\hline $\begin{array}{l}\text { Born in Sweden with both } \\
\text { parents born in another } \\
\text { country }\end{array}$ & 4.8 & 6.1 & \\
\hline
\end{tabular}


Born in Sweden with one parent born in another country

Born in another country

\begin{tabular}{lrr} 
The Nordic countries & 3.5 & 16.9 \\
EU 12 & 1.9 & 9.3 \\
Other countries in Europe & 3.2 & 15.2 \\
Africa & 0.7 & 3.4 \\
North America & 1.8 & 8.5 \\
South America & 2.3 & 11.0 \\
Asia & 7.1 & 33.9 \\
Oceania & 0.0 & 0.0 \\
Soviet Union & 0.4 & 1.7 \\
Year of arrival* & & \\
1945-65 & & 5.1 \\
1966-1972 & & 6.8 \\
1973-1985 & & 22.0 \\
1986-1993 & & 53.4 \\
1994-1999 & & 11.9 \\
\hline & & \\
Number of observations & 563 & 445 \\
\hline
\end{tabular}


Table 12. Multinomial logit for the probability of following different paths for individuals who were employed in the TEI in 1999. Standard errors in parentheses

\begin{tabular}{ccc}
\hline Variables & $\begin{array}{c}\text { Employed in a TEA in } 1998 \\
\text { and } 2000\end{array}$ & $\begin{array}{c}\text { Unemployed in } 1998 \text { and employed in All other paths (comparison } \\
\text { another industry in 2000 }\end{array}$ \\
group)
\end{tabular}

\section{Woman}

$-0.0385(0.0403)$

$-0.5594(0.0902)^{* * *}$

Place of birth

Sweden

North

West

East

South

Second generation immigrant

Age group

$16-20$
$21-25$
$26-30$
$31-35$
$36-40$
$41-45$
$46-50$
$51-55$
$56-60$
$61-65$

Highest educational level

Primary school less than 9 years

Primary school 9 (10) years

Upper secondary 2 years or less

Upper secondary 2 years or more

Higher education less than 3 years

Higher education 3 years or more

Post-graduate education

$$
\begin{gathered}
\text { reference } \\
-0.0006(0.0986) \\
-0.0873(0.1566) \\
-0.9151(0.1420)^{* * *} \\
-0.4250(0.0923)^{* * *}
\end{gathered}
$$

$-0.1818(0.1014)^{*}$

$$
\begin{gathered}
-2.7572(0.1719)^{* * *} \\
-1.4281(0.0869)^{* * *} \\
-0.8019(0.0784)^{* * *} \\
-0.3290(0.0735)^{* * *} \\
-0.1540(0.0770)^{*} \\
\text { reference } \\
0.2428(0.0783)^{* * *} \\
0.2084(0.0807)^{* *} \\
0.4505(0.0944)^{* * *} \\
0.6252(0.1525)^{* * *}
\end{gathered}
$$

$$
\begin{gathered}
0.2580(0.0953) * * * \\
0.1111(0.0652)^{*} \\
0.0133(0.5660) \\
\text { reference } \\
-0.2696(0.0657) * * \\
0.0851(0.0715) \\
0.5526(0.5975)
\end{gathered}
$$

\section{Marital status}

\section{Unmarried}

Married

Divorced

\section{Stockholm}

Gothenburg

Malmoe

$$
\begin{gathered}
\text { reference } \\
-0.0435(0.4788) \\
-0.2393(0.0636)^{* * *} \\
-0.4537(0.0434)^{* * *} \\
-0.2301(0.0631)^{* * *} \\
-0.0179(0.0958)
\end{gathered}
$$

$-0.4660(0.0815)^{* * *}$ reference

$0.2925(0.2380)$

$0.6546(0.2783) * *$

$0.1069(0.2390)$

$0.5807(0.1464) * * *$

$0.1694(0.2051)$
Constant

Number of observations
$-29.5892(313177.8)$
$-0.5274(0.1979) * * *$
$0.1638(0.1804)$
$0.2787(0.1769)$
$0.2840(0.1863)$
reference
$0.0061(0.2143)$
$0.0564(0.2195)$
$-0.2929(0.3060)$
$-1.6542(1.0186)$

$-0.6541(0.3095) * *$

$-0.2400(0.1496)$

$0.0332(0.1200)$

reference

$-0.4070(0.1454) * * *$

$-0.3989(0.1771)^{* *}$

1.3994 (0.8319)*

reference

$-0.0112(0.1131)$

$0.0208(0.1541)$

$-0.3938(0.0972)^{* * *}$

$-0.4769(0.1569) * * *$

$-0.1488(0.2297)$
$-2.5031(0.1934) * * *$

18296


Table 13. Annual earnings for those working in a TEA in 1999 with different mobility pattern; all, natives, immigrants.

\begin{tabular}{|c|c|c|c|c|c|c|c|}
\hline Group & $\begin{array}{c}\text { Number of } \\
\text { observations }\end{array}$ & Year & Mean & St.dev. & Min. & Max. & Median \\
\hline \multirow[t]{3}{*}{ All } & \multirow[t]{3}{*}{18173} & 1998 & 123260 & 105716 & 0 & 1095072 & 108723 \\
\hline & & 1999 & 156164 & 94773 & 180 & 980191 & 147936 \\
\hline & & 2000 & 189120 & 108800 & 0 & 1173500 & 185618 \\
\hline \multirow[t]{3}{*}{ Natives } & \multirow[t]{3}{*}{15741} & 1998 & 127467 & 107150 & 0 & 1095072 & 115760 \\
\hline & & 1999 & 158189 & 96608 & 180 & 980191 & 149265 \\
\hline & & 2000 & 190540 & 110416 & 0 & 1173500 & 185706 \\
\hline \multirow[t]{3}{*}{ Immigrants } & \multirow[t]{3}{*}{2432} & 1998 & 96027 & 91366 & 0 & 552144 & 75285 \\
\hline & & 1999 & 143057 & 80704 & 187 & 712131 & 136789 \\
\hline & & 2000 & 179929 & 97221 & 0 & 805666 & 184532 \\
\hline \multirow{3}{*}{$\begin{array}{l}\text { Employed in a TEA } \\
\text { in } 1998,1999 \text { and } \\
\text { 2000. All }\end{array}$} & \multirow[t]{3}{*}{3943} & 1998 & 175153 & 102648 & 3386 & 945000 & 162800 \\
\hline & & 1999 & 193913 & 101186 & 198 & 952000 & 176726 \\
\hline & & 2000 & 203808 & 117017 & 174 & 995763 & 183215 \\
\hline \multirow{3}{*}{$\begin{array}{l}\text { Unemployed in } 1998 \\
\text { and employed in } \\
\text { another industry in } \\
\text { 2000. All }\end{array}$} & \multirow[t]{3}{*}{561} & 1998 & 23521 & 32545 & 0 & 192501 & 11317 \\
\hline & & 1999 & 107643 & 51302 & 4942 & 309697 & 104068 \\
\hline & & 2000 & 201696 & 71051 & 5458 & 423042 & 202867 \\
\hline \multirow{3}{*}{$\begin{array}{l}\text { Employed in a TEA } \\
\text { in } 1998,1999 \text { and } \\
\text { 2000. Natives }\end{array}$} & \multirow[t]{3}{*}{3493} & 1998 & 177681 & 103872 & 3386 & 945000 & 163827 \\
\hline & & 1999 & 195557 & 103086 & 198 & 952000 & 176569 \\
\hline & & 2000 & 205268 & 118949 & 174 & 995763 & 182909 \\
\hline \multirow{3}{*}{$\begin{array}{l}\text { Unemployed in } 1998 \\
\text { and employed in } \\
\text { another industry in } \\
\text { 2000. Natives }\end{array}$} & \multirow[t]{3}{*}{444} & 1998 & 24708 & 33961 & 0 & 192501 & 12054 \\
\hline & & 1999 & 106443 & 49364 & 15431 & 309697 & 103715 \\
\hline & & 2000 & 198336 & 69744 & 5458 & 423042 & 199169 \\
\hline \multirow{3}{*}{$\begin{array}{l}\text { Employed in a TEA } \\
\text { in } 1998,1999 \text { and } \\
\text { 2000. Immigrants }\end{array}$} & \multirow[t]{3}{*}{450} & 1998 & 155524 & 90317 & 12257 & 552144 & 151774 \\
\hline & & 1999 & 181152 & 84016 & 6268 & 597962 & 178551 \\
\hline & & 2000 & 192474 & 100160 & 4565 & 733368 & 186236 \\
\hline \multirow{3}{*}{$\begin{array}{l}\text { Unemployed in } 1998 \\
\text { and employed in } \\
\text { another industry in } \\
\text { 2000. Immigrants }\end{array}$} & \multirow[t]{3}{*}{117} & 1998 & 19015 & 26131 & 0 & 128107 & 8233 \\
\hline & & 1999 & 112195 & 58084 & 4942 & 304530 & 108662 \\
\hline & & 2000 & 214447 & 74748 & 12793 & 368560 & 219827 \\
\hline
\end{tabular}


Table 14. Gross yearly labour income (earnings and employment-related transfer payments) for those working in a TEA in 1999 for groups with different mobility pattern; all, natives, immigrants.

\begin{tabular}{|c|c|c|c|c|c|c|c|}
\hline Group & $\begin{array}{c}\text { Number of } \\
\text { observations }\end{array}$ & Year & Mean & St.dev & Min & Max & Median \\
\hline \multirow[t]{3}{*}{ All } & \multirow[t]{3}{*}{18173} & 1998 & 135954 & 102471 & 0 & 1095072 & 131438 \\
\hline & & 1999 & 168477 & 90599 & 800 & 980191 & 161585 \\
\hline & & 2000 & 201915 & 101767 & 0 & 1173500 & 193745 \\
\hline \multirow[t]{3}{*}{ Born in Sweden } & \multirow[t]{3}{*}{15741} & 1998 & 139846 & 103832 & 0 & 1095072 & 136607 \\
\hline & & 1999 & 170107 & 92554 & 800 & 980191 & 162259 \\
\hline & & 2000 & 202944 & 103687 & 0 & 1173500 & 193681 \\
\hline \multirow[t]{3}{*}{ Immigrants } & \multirow[t]{3}{*}{2432} & 1998 & 110768 & 89184 & 0 & 552144 & 96831 \\
\hline & & 1999 & 157928 & 75920 & 9463 & 712131 & 157024 \\
\hline & & 2000 & 195259 & 88061 & 0 & 805666 & 194294 \\
\hline \multirow{3}{*}{$\begin{array}{l}\text { Employed in a TEA in } \\
1998,1999 \text { and } 2000 . \\
\text { All }\end{array}$} & \multirow[t]{3}{*}{3943} & 1998 & 184956 & 98223 & 10191 & 945000 & 167361 \\
\hline & & 1999 & 203940 & 95244 & 800 & 952000 & 181095 \\
\hline & & 2000 & 217478 & 108733 & 6004 & 995763 & 190687 \\
\hline \multirow{3}{*}{$\begin{array}{l}\text { Unemployed in } 1998 \\
\text { and employed in } \\
\text { another industry in } \\
\text { 2000. All }\end{array}$} & \multirow[t]{3}{*}{561} & 1998 & 75788 & 44282 & 1200 & 219801 & 71565 \\
\hline & & 1999 & 139287 & 45688 & 39486 & 309930 & 140184 \\
\hline & & 2000 & 216702 & 60295 & 15334 & 423042 & 211328 \\
\hline \multirow{3}{*}{$\begin{array}{l}\text { Employed in a TEA in } \\
1998,1999 \text { and } 2000 . \\
\text { Natives }\end{array}$} & \multirow[t]{3}{*}{3493} & 1998 & 187055 & 99564 & 10191 & 945000 & 167861 \\
\hline & & 1999 & 205317 & 97313 & 800 & 952000 & 181039 \\
\hline & & 2000 & 218856 & 110736 & 6004 & 995763 & 190687 \\
\hline \multirow{3}{*}{$\begin{array}{l}\text { Unemployed in } 1998 \\
\text { and employed in } \\
\text { another industry in } \\
\text { 2000. Natives }\end{array}$} & \multirow[t]{3}{*}{444} & 1998 & 77086 & 45310 & 1200 & 219801 & 73293 \\
\hline & & 1999 & 138399 & 43131 & 39486 & 309697 & 140187 \\
\hline & & 2000 & 213401 & 59235 & 56116 & 423042 & 208414 \\
\hline \multirow{3}{*}{$\begin{array}{l}\text { Employed in a TEA in } \\
1998,1999 \text { and } 2000 . \\
\text { Immigrants }\end{array}$} & \multirow[t]{3}{*}{450} & 1998 & 168340 & 85421 & 12657 & 552144 & 164110 \\
\hline & & 1999 & 193249 & 76578 & 23400 & 597962 & 181511 \\
\hline & & 2000 & 206784 & 91113 & 30000 & 733368 & 190911 \\
\hline \multirow{3}{*}{$\begin{array}{l}\text { Unemployed in } 1998 \\
\text { and employed in } \\
\text { another industry in } \\
\text { 2000. Immigrants }\end{array}$} & \multirow[t]{3}{*}{117} & 1998 & 70864 & 39941 & 4300 & 177300 & 67142 \\
\hline & & 1999 & 142659 & 54390 & 47040 & 309930 & 139734 \\
\hline & & 2000 & 229229 & 62849 & 15334 & 376793 & 225882 \\
\hline
\end{tabular}

